\title{
Phosphatase and Carbocyanine Dye Binding Define Different Types of Phosphate Groups in Mammalian Neurofilaments
}

\author{
H. Ksiezak-Reding and S.-H. Yen \\ Department of Pathology, Albert Einstein College of Medicine, Bronx, New York 10461
}

\begin{abstract}
The phosphorylation state of human and bovine spinal cord neurofilaments (NF) was studied by direct phosphate analysis and carbocyanine dye ("Stains-all') binding to NF polypeptides resolved on SDS-polyacrylamide gels. Electrophoretically purified NF-H (200 kDa), NF-M (160 kDa), and NF-L (68 kDa) of human origin contained 24,18 , and 4 mol phosphate/mol protein, whereas bovine NF contained 53,23 , and 5 mol phosphate/mol protein, respectively. Incubation of NF preparations with $E$. colialkaline phosphatase removed about $55 \%$ of the phosphate from NF-H, about $30 \%$ of the phosphate from both human and bovine NF-M, but did not change the phosphate content of NF-L. This treatment also inhibited or substantially reduced the binding of electroblotted NF-H and NF-M to 2 anti-NF monoclonal antibodies known to recognize phosphorylated sites on projection side arms. "Stainsall" was found to be a very sensitive probe for detection of phosphorylated cytoskeletal proteins. Without the phosphatase treatment, NF and other phosphoproteins, MAP1, MAP2, tubulin, and tau, all bound the carbocyanine dye on SDS gels, forming blue dye-protein complexes. Measured densitometrically at $615 \mathrm{~nm}$, the staining intensity (relative units/ mol protein) was 9,9 , and 3 for human and 10,13, and 6 for bovine NF-H, NF-M, and NF-L, respectively. NF-H bound the dye less efficiently than was expected from its phosphate content. After phosphatase treatment, NF-H, with half of its phosphate residues remaining, no longer formed blue complex with "Stains-all," the staining intensity of NF-M decreased by $20-40 \%$, and the staining of NF-L was not changed. The results of dye binding, phosphate analysis, and immunostaining showed that there are at least 2 sets of phosphate groups in mammalian NF, which react differently with the phosphatase.
\end{abstract}

Neurofilaments (NF) are composed of 3 phosphoproteins, with molecular weights of about $200 \mathrm{kDa}(\mathrm{NF}-\mathrm{H}), 160 \mathrm{kDa}(\mathrm{NF}-\mathrm{M})$, and $68 \mathrm{kDa}$ (NF-L) that vary between species (Chiu et al., 1980; Lasek et al., 1985). NF-H has been shown to contain the highest amount of phosphate and NF-L the least (Jones and Williams, 1982; Julien and Mushynski, 1982; Wong et al., 1984; Carden

\footnotetext{
Received Oct. 27, 1986; revised May 7, 1987; accepted May 8, 1987.

The authors thank C.-H. Chien for technical assistance and Drs. F.-C. Chiu and D. W. Dickson for their comments on the manuscript. This work has been supported by NIH Grants AG1 136 and AG4145 and USpHS Training Grant NS07098 (H.K.-R).

Correspondence should be addressed to S.-H. Yen, Ph.D., Department of Pathology, Albert Einstein College of Medicine, 1300 Morris Park Avenue, Bronx, NY 10461.

Copyright @ 1987 Society for Neuroscience $0270-6474 / 87 / 113554-07 \$ 02.00 / 0$
}

et al., 1985). Phosphorylation of NF proteins has been demonstrated in vivo (Eagles et al., 1981; Julien and Mushynski, 1981; Honchar et al., 1982; Shecket and Lasek, 1982). However, only limited information is available regarding the enzymes involved in this process. In vitro studies showed that phosphorylation of NF could be catalyzed by cAMP, $\mathrm{Ca}^{2+}$-independent protein kinases (Runge et al., 1981; Julien et al., 1983; ToruDelbauffe and Picrre, 1983), or by calmodulin-dependent protein kinases (Vallano et al., 1985). These enzymes were detected in NF-enriched preparations. Dephosphorylation of NF proteins in tissue sections or test tubes has been achieved by incubation with alkaline phosphatases from $E$. coli or calf intestine (Julien and Mushynski, 1982; Sternberger and Sternberger, 1983; Carden et al., 1985; Georges et al., 1986). Upon dephosphorylation, there is an increase in the electrophoretic mobility of NF-H and NF-M, but not of NF-L.

Immunocytochemical studies demonstrated that certain antigenic determinants of phosphorylated NF are expressed in axons, but not in neuronal cell bodies (Sternberger and Sternberger, 1983). The significance of such "heterogeneity" is uncertain. The axon-specific anti-NF antibodies were recently shown to recognize filaments that had accumulated abnormally in neuronal cell bodies after exposure to some neurotoxins (Troncoso et al., 1985), and they also reacted with neurofibrillary tangles found in Alzheimer's disease (Sternberger et al., 1985; Yen et al., 1985; Cork et al., 1986) and other neuropathological conditions (Nakazato et al., 1984). Furthermore, many tanglereactive anti-NF antibodies were recently found to recognize the heat-stable, phosphorylated microtubule-associated proteins tau and MAP2 (Ksiezak-Reding and Yen, 1987; KsiezakReding et al., 1987; Nukina et al., 1987). These observations have led to the hypothesis that the phosphorylation state of NF or other associated cytoskeletal components may affect the distribution or movement of NF. An understanding of the phosphorylation of NF at different subcellular locuses, in normal versus pathological conditions and in different species, would be important for studying the role of NF phosphorylation.

The phosphate content of NF triplet proteins from animal tissues has been studied by several laboratories (Jones and Williams, 1982; Julien and Mushynski, 1982; Wong et al., 1984; Carden et al., 1985; Georges et al., 1986). No information, however, is available regarding the state of phosphorylation of NF derived from human tissues. Such data may provide some clue as to why neurofibrillary degeneration of the Alzheimer's type occurs only in humans. In the following studies, 2 methods were used to analyze the state of phosphorylation of human NF proteins. The results are compared with those obtained from nonhuman tissues. 


\section{Materials and Methods}

Preparation of NF and microtubules. Human spinal cords (4-14 hr postmortem) and bovine spinal cords obtained from a local slaughterhouse were stored at $-80^{\circ} \mathrm{C}$ before use. The NF-enriched samples were prepared by the method of Chiu and Norton (1982). The resulting pellet was suspended in a buffer containing $0.1 \mathrm{M}$ Tris- $\mathrm{HCl}, \mathrm{pH} 8.0,1 \mathrm{~mm}$ $\mathrm{MgSO}_{4}, 1 \mathrm{~mm}$ EGTA, $0.1 \mathrm{~mm}$ EDTA, and $2 \mathrm{~mm}$ phenylmethylsulfonyl fluoride, or in a similar buffer without $\mathrm{MgSO}_{4}, \mathrm{EGTA}$, and EDTA. NF (3 $\mathrm{mg}$ of protein) were incubated with $50 \mathrm{U} / \mathrm{ml}$ of $E$. coli alkaline phosphatase (Sigma, type III) for $16 \mathrm{hr}$ at $37^{\circ} \mathrm{C}$. The addition of $\mathrm{MgSO}_{4}$, EGTA, and EDTA to the incubation medium improved the reaction to some extent. A control sample was incubated similarly without the phosphatase. The enzyme-treated and control samples were centrifuged for $10 \mathrm{~min}$ at $10,000 \times \mathrm{g}$. In some experiments, the NF preparation was suspended in the above buffer (adjusted to $\mathrm{pH} 6.5$ ) and incubated with neuraminidase (Sigma, type $\mathrm{X}$ ), $1 \mathrm{U} / \mathrm{ml} / 3 \mathrm{mg} \mathrm{NF}$ protein, in the same conditions as for the alkaline phosphatase.

The microtubule fraction was prepared from bovine brain by double cycle of polymerization, according to the procedure reported by Murphy (1982) with minor modifications (Ksiezak-Reding and Yen, 1987). Protein content was determined by the method of Lowry et al. (1951).

Gel electrophoresis and staining with "Stains-all." SDS-gel electrophoresis was performed on 7.5 or $10 \%$ polyacrylamide gels $(1.5 \mathrm{~mm}$ thick) using the discontinuous system of Laemmli (1970). To stain phosphoproteins on gels, we used a modification of the procedures described by Green et al. (1973) and Campbell et al. (1983). The gels were fixed overnight in $25 \%$ methanol/10\% acetic acid and then washed for $3 \mathrm{hr}$ in $25 \%$ methanol ( 3 changes) and for $2 \mathrm{hr}$ in $25 \%$ methanol$30 \mathrm{~mm}$ Tris- $\mathrm{HCl}, \mathrm{pH} 8.8$ ( 2 changes). The gels were stained overnight (in the dark) with a freshly prepared cationic carbocyanine dye solution containing $25 \%$ methanol, $7.5 \%$ formamide, $30 \mathrm{~mm}$ Tris- $\mathrm{HCl}, \mathrm{pH} 8.8$, and $0.0025 \%$ l-cthyl-2-/3-(1-cthylnaphto/1,2d/thiazolin-2-ylidenc)-2methyl-propenyl/-naphto/1,2d/thiazolium bromide (the cationic carbocyanine dye; Sigma, "Stains-all"). The stained gels were washed for $\mathrm{l} \mathrm{hr}$ in $25 \%$ methanol ( 2 changes) and were photographed through a red filter. The gels were completely destained by repetitive washes as above, then stained with Coomassie blue or Fast green as described earlier (Gorovsky et al., 1970). Fast green was more reliable than Coomassie blue in the quantitive analysis of NF proteins (Chiu and Norton, 1982). Gels stained with "Stains-all" and those stained with Fast green were scanned on a Gilford spectrophotometer at 615 and $660 \mathrm{~nm}$, respectively. The area under each peak was determined by an integrator or by weighing the paper. Ovalbumin was used as a standard in the quantitative analysis of the Fast green-stained proteins.

Determination of phosphate content of $N F$ proteins. The individual NF polypeptides used for phosphate analysis were separated by SDSPAGE. The respective protein bands were identified by incubating the gels with $4 \mathrm{~m}$ sodium acetate for $30 \mathrm{~min}$ (Higgins and Dahmus, 1979). The excised gel strips were washed in distilled water $(2 \times 10 \mathrm{~min})$, cut into small pieces, and subjected to electroelution in an ISCO electrophoretic concentrator (Model 1750; ISCO). The inner and sample chambers contained $2.5 \mathrm{~mm}$ Tris-base, $19.2 \mathrm{~mm}$ glycine, and $0.05 \%$ SDS, and the electrode chamber contained $25 \mathrm{~mm}$ Tris-base, $192 \mathrm{~mm}$ glycine, and $0.05 \%$ SDS. Electroelution was carried out for $4-5 \mathrm{hr}$ at room temperature. The 100-250 $\mu$ laliquots of the eluate were dried and ashed twice with $30 \mu \mathrm{l}$ of $10 \% \mathrm{Mg}\left(\mathrm{NO}_{3}\right)_{2} \times 6 \mathrm{H}_{2} \mathrm{O}$ in $95 \%$ ethanol (Ames, 1966). The residues were dissolved in $0.5 \mathrm{~N} \mathrm{HCl}$, boiled for $20 \mathrm{~min}$, and the samples were analyzed for inorganic phosphate content by the microadaptation of the malachite green method of Itaya and Ui (1966). A standard solution of inorganic phosphate (Sigma) was also subjected to the ashing procedure. Respective controls were performed for ashing efficiency (with ovalbumin) and for interference of the elution buffer and magnesium nitrate.

Immunoblotting. NF proteins separated on SDS gels were electrophoretically transferred to nitrocellulose paper (Towbin et al., 1979). Immunoblotting was carried out with 2 well-characterized monoclonal anti-NF antibodies, AD10 and Ab18, as reported previously (Yen et al., 1985; Ksiezak-Reding and Yen, 1987).

\section{Results}

Binding of "Stains-all" dye to NF and other phosphoproteins The NF-enriched samples prepared from human and bovine spinal cords, in addition to NF triplet proteins, contained glial filament proteins and other polypeptides. In most of the preparations, only NF proteins were stained blue by the cationic carbocyanine dye (Fig. 1). Other protein bands were stained red. The intensity of the blue staining of NF proteins correlated well with the protein content. In the microtubule fraction, several protein bands also formed blue complexes with the dye (Fig. 1). These included microtubule-associated protein (MAP)1, MAP2, tau proteins, tubulin, and proteins that comigrated with NF polypeptides on SDS gels.

\section{Decreased binding of "Stains-all" and anti-NF antibodies to phosphatase-treated NF}

The electrophoretic mobility of NF-H and NF-M obtaincd from either human or bovine spinal cord was changed after incubation of the NF preparation with phosphatase (Fig. $2 A$ ). For the human, the apparent molecular weights of NF-H and NF-M were reduced to about 180 and $150 \mathrm{kDa}$, respectively, and for bovine, to 170 and $150 \mathrm{kDa}$, respectively. The molecular weight of NF-L from both species, by contrast, was not altered. Our results are comparable to those reported to other investigators (Carden et al., 1985; Kaspi and Mushynski, 1985).

NF-H in the phosphatase-treated NF preparations from both species was no longer stained blue by "Stains-all"; instead, it was stained red (Fig. 2B). NF-M retained the ability to form blue complex with the dye, but the intensity of staining was decreased as compared to that of the untreated samples. No apparent changes were detected in the staining of NF-L by the dye.

Electroblotted NF-H and NF-M from untreated preparations reacted with 2 anti-NF monoclonal antibodies, $\mathrm{AD} 10$ and $\mathrm{Ab} 18$ (Fig. 2C). These antibodies have been previously found to recognize phosphorylated sites on NF-H and NF-M (Ksiezak-Reding and Yen, 1987). Treatment of NF preparation with phosphatase blocked the binding of AD10 to NF-H and NF-M. It also reduced the binding of $A b 18$ to NF proteins.

\section{Quantitative analysis of phosphate content and "Stains-all" binding in NF proteins}

Quantitative phosphate analysis of human and bovine NF proteins showed that NF-H and NF-M in both species were more phosphorylated than was NF-L (Table 1). Furthermore, bovine $\mathrm{NF}-\mathrm{H}$ was found to contain twice as much phosphate $(53 \mathrm{~mol})$ per mol protein as human NF-H $(24 \mathrm{~mol})$. The species differences were not so striking in the other two NF proteins. Bovine phosphate content of NF-M (23 mol) was only moderately higher than human (18 mol). Bovine and human NF-L contained similar amounts of phosphate -5 and 4 mol, respectively.

The phosphatase treatment of NF preparations from both species reduced the amount of phosphate by $50-60 \%$ in NF-H and by $28-30 \%$ in NF-M (Table 1). The phosphate groups in NF-L were apparently insensitive to the enzyme under these conditions.

By comparing the intensity of staining of NF proteins resolved on SDS gels with the carbocyanine dye and Fast green it became apparent that there was a linear relationship between "Stainsall" binding and the amount of protein (Fast green) for each individual NF polypeptide (Fig. 3). Since the ratio of binding (in arbitrary units) of "Stains-all" to Fast green was always higher than 1 for the untreated NF polypeptides, "Stains-all" appeared to be a more sensitive probe in detecting the phosphoproteins than was Fast green. In human preparations, the ratios of "Stains-all" binding to that of Fast green were 1.3, 1.7, 


\section{Coomassie Blue}

(A)

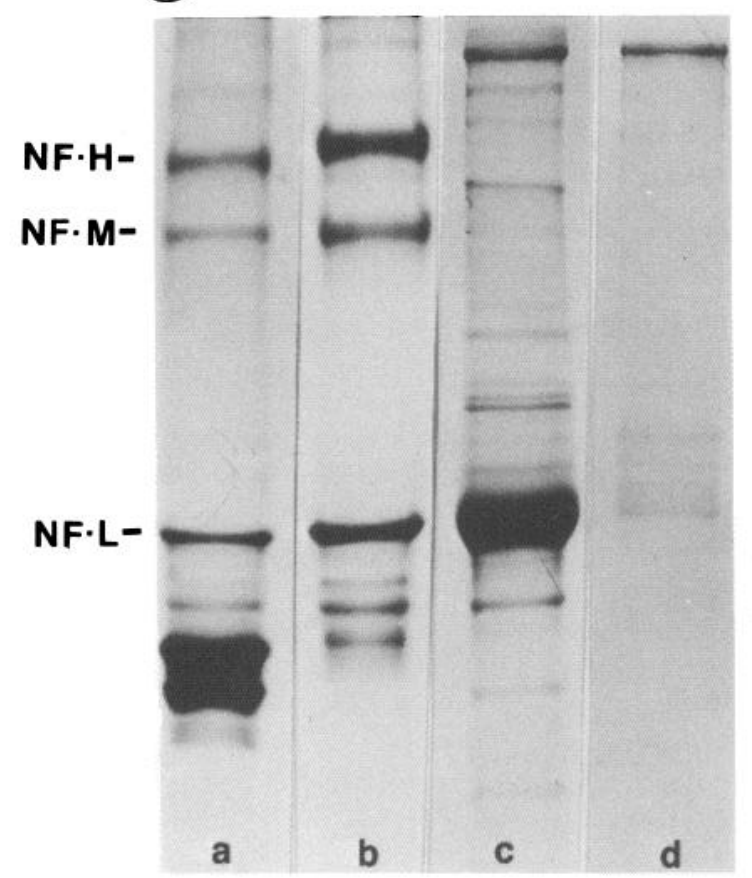

(B)

"Stains - All"

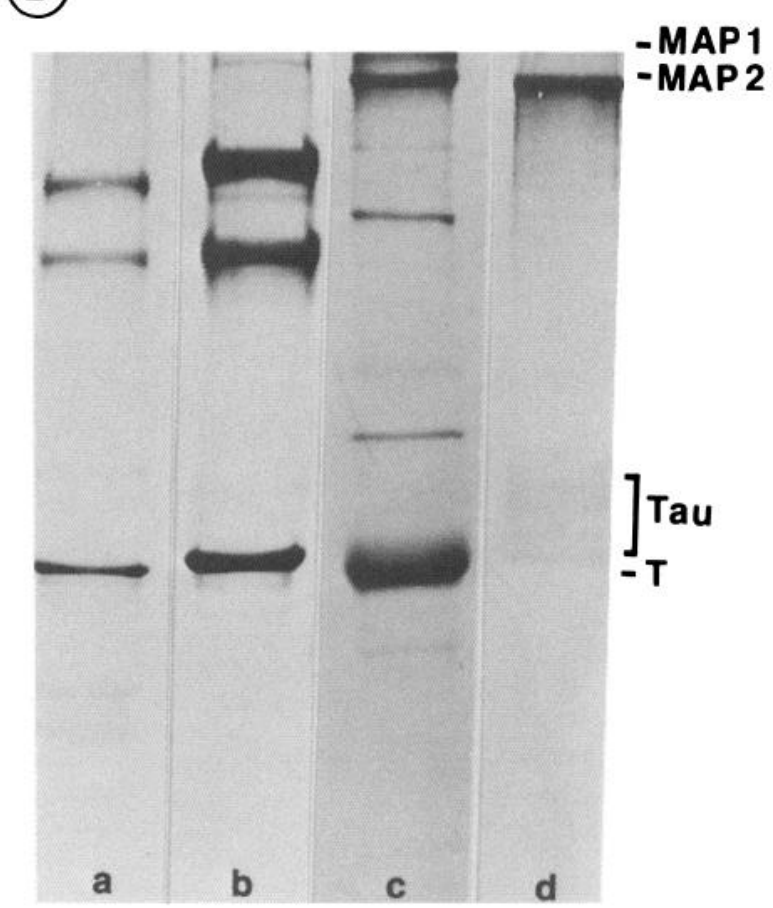

Figure 1. Coomassie blue $(A)$ and "Stains-all" $(B)$ double staining of NF preparations from $(a)$ human or $(b)$ bovine spinal cords, $(c)$ microtubule fraction from bovine brain, and $(d)$ heat-stable microtubule fraction from bovine brain. SDS-polyacrylamide gels, $7 \%(a, b)$ or $10 \%(c, d)$ were first stained with "Stains-all," and a photograph was taken through a red filter. Gels were then destained and stained again with Coomassie blue. The location of NF triplet proteins, as well as of MAP1, MAP2, tau and beta-tubulin $(T)$ is indicated.

and 1.3 for untreated NF-H, NF-M, and NF-L, respectively, and $0.1,1.0$, and 1.5 for the respective phosphatase-treated NF. In bovine preparations, the ratios of "Stains-all" binding to that of Fast green were 1.6, 2.6, and 2.5 for the untreated NF triplet, respectively. After phosphatase treatment, they decreased to 0 , 2.1 , and 2.5 for the respective NF.

The binding of "Stains-all" (relative units) per mol of each of the NF triplet proteins (Table 2) showed that, in analogy to

\section{(A)}

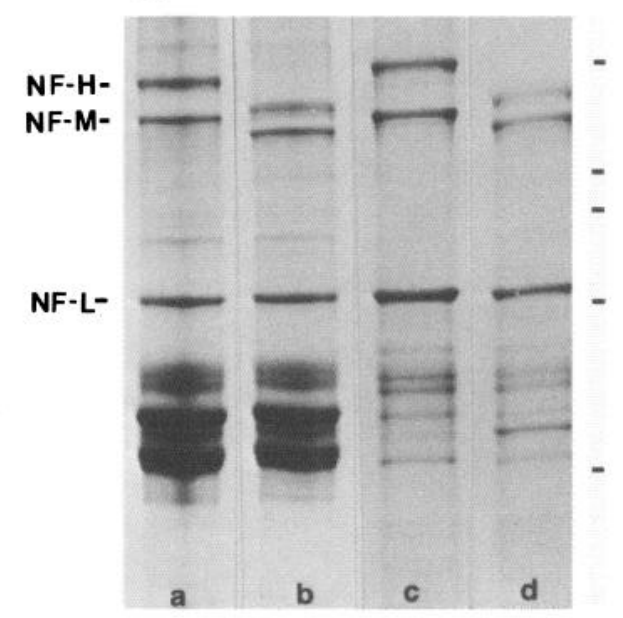

\section{(B)}

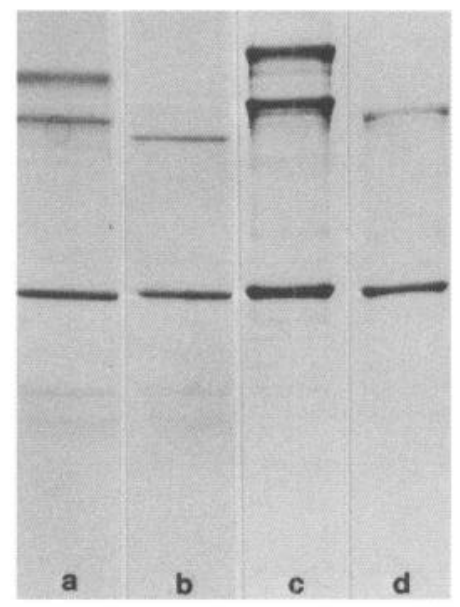

(C)

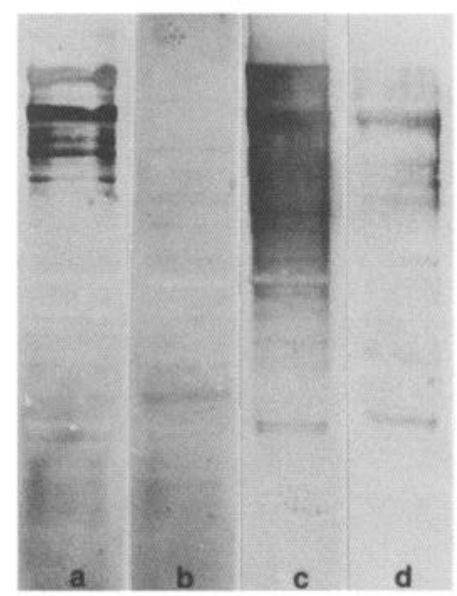

Figure 2. Coomassie blue $(A)$ and "Stains-all" $(B)$ double staining, and immunoblots $(C)$ of control and phosphatase-treated NF preparations resolved on $10 \%$ SDS gels. In $A$ and $B$, double staining was performed as described in Figure 1 for $(a)$ untreated or $(b)$ phosphatase-treated NF preparation from human, and $(c)$ untreated or $(d)$ phosphatase-treated NF preparation from bovine. $C$, Electroblotted NF proteins of bovine from $(a)$ untreated or $(b)$ phosphatase-treated NF preparations stained with AD10, and $(c)$ untreated or $(d)$ phosphatase-treated NF preparations stained with Ab18. The locations of NF-H, NF-M, and NF-L are indicated. Marks at right $(A)$ correspond to standard proteins of molecular weight (from top) $205 \mathrm{kDa}$ (myosin), $116 \mathrm{kDa}$ (beta-galactosidase), $97 \mathrm{kDa}$ (phosphorylase $\mathrm{B}), 66 \mathrm{kDa}$ (albumin, bovine) and $45 \mathrm{kDa}$ (albumin, egg). 

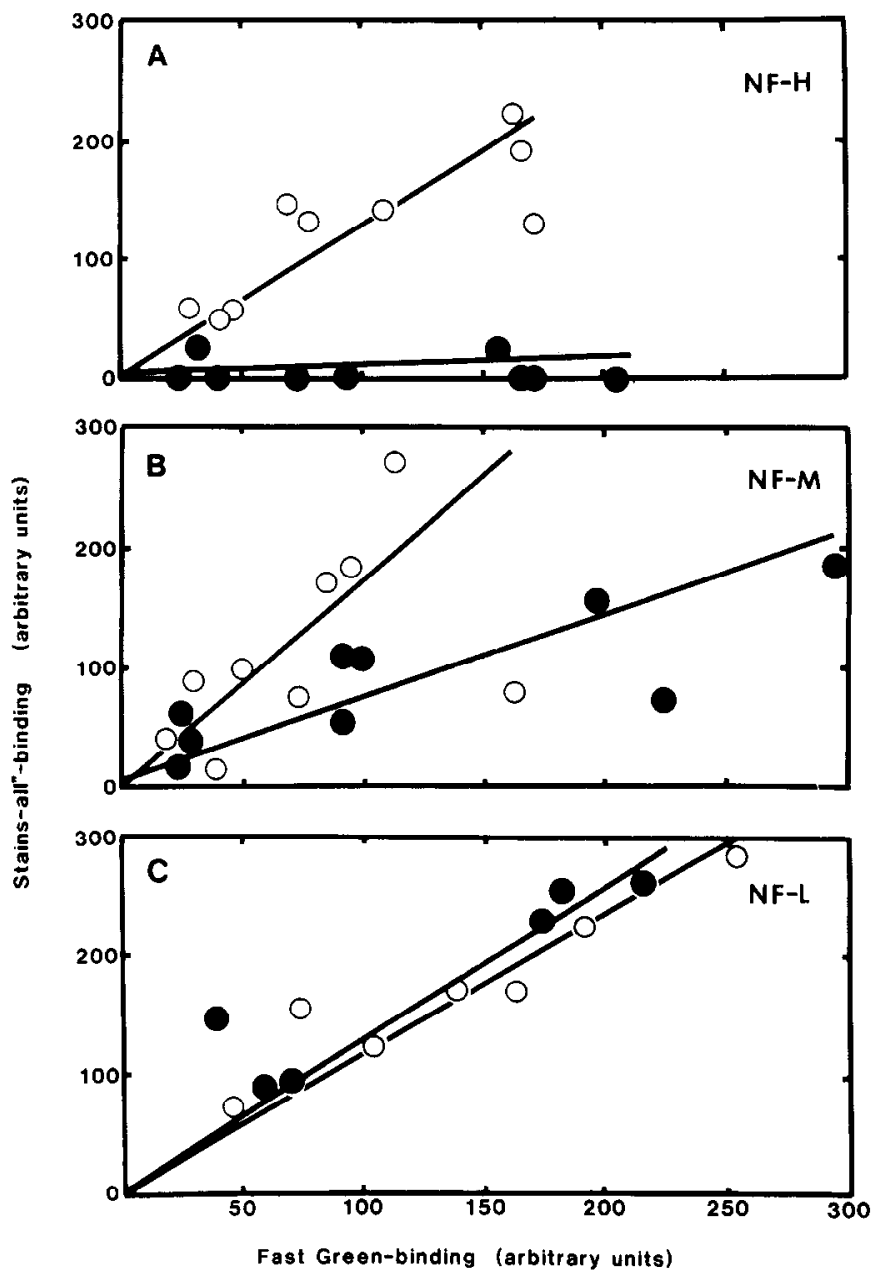

Figure 3. The relation between "Stains-all" binding (blue complex) and amount of protein (Fast green binding) in triplet NF polypeptides from human spinal cord. NF-H $(A)$, NF-M $(B)$, and NF-L $(C)$ were resolved on SDS gels, stained with "Stains-all" or Fast green, and scanned at 610 or $660 \mathrm{~nm}$, respectively. Areas under each peak were measured and expressed in arbitrary units. Untreated (open circles) and phosphatase-treated (filled circles) NF preparations. Each point represents an individual measurement.

Table 1. Phosphate content of human and bovine neurofilament triplet polypeptides

\begin{tabular}{lllll} 
Species & $\begin{array}{l}\text { No } \\
\text { treatment } \\
\text { polypeptide }\end{array}$ & $\begin{array}{l}\text { Alkaline } \\
\text { phosphat P/mol } \\
\text { treatment } \\
\text { protein) }\end{array}$ & $\begin{array}{l}\text { Phosphate } \\
\text { protein) }\end{array}$ & $\begin{array}{l}\text { groups } \\
\text { removed } \\
\text { (mol P/mol } \\
\text { protein) }\end{array}$ \\
\hline Human & NF-H & $24 \pm 4$ & $12 \pm 3$ & 12 \\
& NF-M & $18 \pm 2$ & $13 \pm 2$ & 5 \\
& NF-L & $4 \pm 1$ & $4 \pm 1$ & 0 \\
Bovine & NF-H & $53 \pm 8$ & $21 \pm 3$ & 32 \\
& NF-M & $23 \pm 1$ & $16 \pm 3$ & 7 \\
& NF-L & $5 \pm 1$ & $4 \pm 1$ & 1
\end{tabular}

Molecular weight of NF triplet polypeptides was assumed to be equal in both species: $200 \mathrm{kDa}$ (NF-H), $160 \mathrm{kDa}$ (NF-M), and $68 \mathrm{kDa}$ (NF-L). Phosphate content was measured in ashed samples of electrophoretically purified NF. Conditions for phosphatase treatment and other details in Materials and Methods. Mean values \pm SEM of 3-6 experiments are presented as mol P/mol protein.
Table 2. Carbocyanine dye "Stains-all" binding in human and bovine neurofilament triplet polypeptides

\begin{tabular}{llccc} 
& & & $\begin{array}{l}\text { Alkaline } \\
\text { phosphatase }\end{array}$ & $\begin{array}{l}\text { Phosphate } \\
\text { groups } \\
\text { removed } \\
\text { (dye }\end{array}$ \\
\hline Human & $\begin{array}{l}\text { NF triplet } \\
\text { poly- } \\
\text { peptide }\end{array}$ & $\begin{array}{l}\text { No treatment } \\
\text { (dye binding/ } \\
\text { mol protein) }\end{array}$ & $\begin{array}{l}\text { (dye binding/ } \\
\text { mol protein) }\end{array}$ & $\begin{array}{l}\text { mol protein) } \\
\text { mol }\end{array}$ \\
\hline \multirow{3}{*}{ Bovine } & NF-H & $9 \pm 1$ & $0.6 \pm 0.5$ & 8 \\
& NF-M & $9 \pm 2$ & $5 \pm 1$ & 4 \\
& NF-L & $3 \pm 0.3$ & $3 \pm 1$ & 0 \\
& NF-H & $10 \pm 1$ & 0 & 10 \\
& NF-M & $13 \pm 3$ & 11 & 2 \\
& NF-L & $6 \pm 1$ & 6 & 0
\end{tabular}

Molecular weight of NF triplet polypeptides was assumed to be equal in both species (see legend to Table 1). Results are expressed in arbitrary units of dye binding/mol protein using Fast green-stained ovalbumin as a protein standard (see Fig. 3 for comparison). Values (dye binding/mol protein) are means \pm SEM for 9-10 gel scans (human) and means \pm range from 2 scans or the results of 1 scan only (bovine). Conditions for phosphatase treatment and other details in Materials and Methods.

direct phosphate analysis, more blue complex is formed per mol of NF-H or NF-M than per mol of NF-L. However, in contrast to the direct phosphate analysis, NF-H and NF-M from human or bovine preparations seem to bind the dye equally in spite of a 1.5-2-fold difference in the phosphate. It appears that NF-H does not bind the dye as efficiently as would be expected from its phosphate content.

The formation of blue complex between NF polypeptides and the carbocyanine dye was reduced by the treatment of NF with phosphatase (Table 2; Fig. 3). The changes correlated to some extent with a reduction of phosphate content. However, the dyebinding method underestimated the quantity of phosphate residues removed from high-molecular-weight NF proteins. This was clearly evident in NF-H from bovine or human preparations.

The results of carbocyanine dye binding showed that this dye is more sensitive than Fast green in detecting untreated NF polypeptides, and that the "Stains-all" binding technique is more suitable for qualitative than for quantitative analysis of phosphate groups in NF polypeptides.

\section{Discussion}

This study shows that NF-H and NF-M prepared from bovine tissue contain more phosphate per mol of protein than does NF-L. These results are in agreement with that reported earlier (Wong et al., 1984; Minami and Sakai, 1985). By comparing human and bovine NF, it is apparent that, with the exception of NF-L, bovine NF proteins contain larger amounts of phosphate than human NF. This difference is not likely due to the postmortem removal of some phosphate groups in human $\mathrm{NF}$, since the electrophoretic mobility of NF polypeptides obtained from fresh postmortem material was similar to that obtained after a longer delay. Furthermore, phosphate residues in isolated NF seem to be relatively stable, since the difference between bovine and human phosphate content of NF polypeptides persisted after $16 \mathrm{hr}$ of incubation at $37^{\circ} \mathrm{C}$. The phosphate content of human NF triplet proteins presented here $(24,18$, and $4 \mathrm{~mol}$ phosphate/mol protein) is similar to that obtained from rat or porcine NF triplet proteins (Julien and Mushynski, 
1982; Georges et al., 1986), which have about 22, 10, and 3 mol phosphate/mol protein.

With regard to the phosphate content of bovine NF proteins, the values reported by different in vestigative groups differ (Jones and Williams, 1982; Wong et al., 1984; Carden et al., 1985; Minami and Sakai, 1985). For NF-H, they vary between 25 and $104 \mathrm{~mol}$ phosphate/mol protein $(200 \mathrm{kDa})$. For NF-M (160 $\mathrm{kDa})$, they range from 10 to 26 , and for NF-L (68 $\mathrm{kDa})$ from 0.4 to 3 . The high variability of phosphate data between laboratories may reflect differences in the assays employed. It may also be affected by the procedures used in purifying NF proteins.

Incubation of NF proteins with alkaline phosphatase $(E$. coli) did not remove all the phosphate groups. In both human and bovine NF, dephosphorylation was more extensive for NF-H than for any other NF protein. In NF-H, up to $60 \%$ of the phosphate residues could be removed, in NF-M about $30 \%$, whereas in NF-L only very little phosphate (if any) could be removed by the enzyme. Treatment of porcine NF with phosphatase (calf intestine or $E$. coli) has been shown to result in a reduction of 63,50 , and $31 \%$ of phosphate content from the respective NF triplet (Georges et al., 1986). A near complete (more than $90 \%$ ) dephosphorylation of NF proteins by phosphatase was observed by Carden et al. (1985). The phosphate content of their untreated NF proteins, however, was much lower than that found by others.

The variable effect of phosphatase on different NF polypeptides could be due to several factors, e.g., a spatial obstruction or an intrinsic resistance of some phosphate group to the enzyme. Such resistance in ovalbumin is known to be due to the specific amino acid sequence surrounding the $\mathrm{P}$-seryl residues (Flavin, 1954). Phosphate groups resistant to the phosphatase treatment have also been found in some cytoskeletal proteins. Incubation of MAP2 with $E$. coli alkaline phosphatase removed only $40-50 \%$ of the phosphate found in that protein (Selden and Pollard, 1983). Other phosphatases, from brain (calcineurin) or smooth muscle (types I and II), acted preferentially on in vitrointroduced phosphate in MAP2, with a very weak reactivity towards in vivo-incorporated ${ }^{32} \mathrm{P}$ (Murthy and Flavin, 1983; Murthy et al., 1985). Whether phosphate groups in NF proteins possess a similar property is not known.

The electrophoretic mobility of NF proteins was changed upon phosphatase treatment. As with that observed in bovine NF (Julien and Mushynski, 1982; Carden el al., 1985; Kaspi and Mushynski, 1985; and the present paper), we found that, in human NF, the increase of mobility was more prominent in $\mathrm{NF}-\mathrm{H}$ than in 2 other proteins, reflecting the extent of NF dephosphorylation. It was already recognized (Kaufmann et al., 1984) that the molecular weight of NF proteins, as determined by the SDS-gel electrophoretic analysis, was much higher than that determined by other techniques. Now it becomes more evident that the discrepancy is due to a large extent to heavy phosphorylation of NF proteins (Carden et al., 1985; Georges et al., 1986; and the present paper). It remains to be tested whether a complete dephosphorylated NF could be shown, using SDS-gel electrophoresis, with a molecular weight comparable to that found by Kaufmann et al. (1984).

The location of the phosphate groups that reacted with phosphatase of the NF molecule remains unknown. A lack of, or weak, reactivity of 2 monoclonal antibodics, known to rccognize phosphorylated sites on NF side arms (Ksiezak-Reding and Yen, 1987), with dephosphorylated NF shows that at least some phosphatase-reactive sites are located on the middle portion of the projection arm of NF-H and NF-M. The other areas of the molecule could be suggested as locations of other, less reactive, groups, e.g., as places limited by the spatial orientation of the molecules in a filament. NF-L, whose phosphate groups were not removed by phosphatase, is believed to form a backbone of the filament, or to be located more centrally than the other 2 NF polypeptides (Willard and Simon, 1981; Chin et al., 1983). In this respect, our data did not support the hypothesis of equal (Francois et al., 1984) exposure of the NF polypeptides to the outside of the filament structure. A detailed localization of phosphate groups on the NF polypeptides is necessary for further discussion.

The carbocyanine dye-binding studies showed that the stain is useful for detecting phosphorylated cytoskeletal proteins, including NF, tubulin, MAP1, MAP2, and tau. According to our analysis of dye binding to the NF triplet, the amount of the blue complex formed is proportional to the protein content and each of the polypeptides has its own characteristic constant. The precise mechanism involved in the staining of phosphoprotein is not known, although it depends on the presence of anionic centers on the protein molecule. Carbocyanine dye has been shown to interact with the phosphoproteins such as casein or phosvitin (Green et al., 1973), as well as with other macromolecules containing sialic acid (Green and Pastewka, 1975; King and Morrison, 1976) or clusters of acidic amino acids as in $\mathrm{Ca}^{2+}$-binding proteins (Campbell et al., 1983; Caday and Steiner, 1985). Since the removal (or blockage by a ligand) of these anionic sites leads to a loss of the blue complex, the carbocyanine dye has been used as a structural probe to monitor ligand-dependent conformational changes in calmodulin (Caday and Steiner, 1985).

The possibility that the sialic acid residues, rather than phosphate groups in NF, could be responsible for the formation of the blue complex with "Stains-all" was ruled out by the lack of effect of neuraminidase on either the electrophoretic mobility or staining characteristic of any of the NF triplet protcins (unpublished observations).

The intensity of staining of the NF polypeptides by carbocyanine dye did not always correlate with the phosphate content of the proteins, especially in NF-H. The relative unit of dye binding/mol protein for $\mathrm{NF}-\mathrm{H}$ was similar to that for NF-M, and it was only 2-3 times that of NF-L. Treatment of NF proteins with alkaline phosphatase affected the binding of the dye to NF-H far more than to NF-M. The dephosphorylated NF$\mathrm{H}$, even though retaining nearly half of its phosphate groups, was no longer detected by the dye, suggesting that the 2 pools of phosphate groups differ substantially, perhaps in their location and/or their influence on the shape of the NF-H molecule, in analogy with the anionic centers in calmodulin (Caday and Steiner, 1985). All the results suggest that the arrangement or the distribution of phosphate groups in NF proteins can be categorized into at least 2 groups; one is easily removed by the phosphatase and the other is not. In NF-H and NF-M the phosphatase-reactive sites are involved in formation of blue complex with "Stains-all," and they exclusively bind 2 monoclonal antibodies. Whether the presence of these different phosphorylated sites depends on the action of different protein kinases or/and phosphatases requires further investigation. It is possible that some phosphate groups in the NF triplet proteins could be incorporated by $\mathrm{Ca}^{2+}$-calmodulin-dependent protein kinase (Vallano et al., 1985) and others by a type II cyclic AMP-dependent protein kinase (Leterrier et al., 1981) associated with MAP2 
(Theurkauf and Vallee, 1982). The precise location of these different phosphorylation sites and their role in the pathology of NF proteins require further study.

\section{References}

Ames, B. N. (1966) Assay of inorganic phosphate, total phosphate and phosphatases. In Methods of Enzymology, vol. 8, S. P. Colowick and N. O. Kaplan, eds., pp. 115-118, Academic, New York.

Caday, C. G., and R. F. Steiner (1985) The interaction of calmodulin with the carbocyanine dye (Stains-all). J. Biol. Chem. 260: 59855990.

Campbell, K. P., D. H. MacLennan, and A. O. Jorgensen (1983) Staining of the $\mathrm{Ca}^{2+}$-binding proteins, calsequestrin, calmodulin, troponin C, and S-100, with the cationic carbocyanine dye "Stains-all." J. Biol. Chem. 258: 11267-11273.

Carden, M. J., W. W. Schlaepfer, and V. M.-Y. Lee (1985) The structure, biochemical properties, and immunogenicity of neurofilament peripheral regions are determined by phosphorylation state. J. Biol. Chem. 260: 9805-9817.

Chin, T. K., P. A. M. Eagles, and A. Maggs (1983) The proteolytic digestion of ox neurofilaments with trypsin and alfa-chymotrypsin. Biochem. J. 215: 239-252.

Chiu, F.C., and W. T. Norton (1982) Bulk preparation of CNS cytoskeleton and the separation of individual neurofilament proteins by gel filtration: Dye-binding characteristics and amino acid compositions. J. Neurochem. 39: 1252-1260.

Chiu, F.-C., B. Korey, and W. T. Norton (1980) Intermediate filaments from bovine, rat and human CNS: Mapping analysis of the major proteins. J. Neurochem. 34: 1149-1 159.

Cork, L. C., N. H. Sternberger, L. A. Sternberger, M. F. Casanova, R. G. Struble, and D. L. Price (1986) Phosphorylated neurofilament antigens in neuritibrillary tangles in Alzheimer's disease. J. Neuropathol. Exp. Neurol. 45: 56-64.

Eagles, P. A. M., D. S. Gilbert, and A. Maggs (1981) The location of phosphorylation sites and $\mathrm{Ca}^{2+}$-dependent proteolytic cleavage sites on the major neurofilament polypeptides from Myxicola infundibulum. Biochem. J. 199: 101-111.

Flavin, M. (1954) The linkage of phosphate to protein in pepsin and ovalbumin. J. Biol. Chem. 210: 771-784.

Francois, C., A. Delacourte, K.-K. Han, and M. Mazzuca (1984) Accessibility and cross-linking of native neurofilaments to chemical reagents. Int. J. Biochem. I6: 461-467.

Georges, E., S. Lefebvre, and W. E. Mushynski (1986) Dephosphorylation of neurofilaments by exogenous phosphatases has no effect on reassembly of subunits. J. Neurochem. 47: 477-483.

Gorovsky, M. A., K. Carlson, and J. L. Rosenbaum (1970) Simple method for quantitive densitometry of polyacrylamide gels using Fast Green. Anal. Biochem. 35: 359-370.

Green, M. R., and J. V. Pastewka (1975) Identification of sialic acidrich glycoproteins on polyacrylamide gels. Anal. Biochem. 65: 6672.

Green, M. R., J. V. Pastewka, and C. Peacock (1973) Differential staining of phosphoproteins on polyacrylamide gels with a cationic carbocyanine dye. Anal. Biochem. 56: 43-51.

Higgins, R. C., and M. E. Dahmus (1979) Rapid visualization of protein bands in preparative SDS-polyacrylamide gels. Anal. Biochem. 93: 257-260.

Honchar, M. P., M. B. Bunge, and H. C. Agrawal (1982) In vivo phosphorylation of neurofilament proteins in the central nervous system of immature rat and rabbit. Neurochem. Res. 7: 365-372.

Itaya, K., and M. Ui (1966) A new micromethod for the colorimetric determination of inorganic phosphate. Clin. Chim. Acta 14:361-366.

Jones, S. M., and R. C. Williams (1982) Phosphate content of mammalian neurofilaments. J. Biol. Chem. 257: 9902-9905.

Julien, J.-P., and W. E. Mushynski (1981) A comparison of in vitroand in vivo-phosphorylated neurofilament polypeptides. J. Neurochem. 37: 1579-1585.

Julien, J.-P., and W. E. Mushynski (1982) Multiple phosphorylation sites in mammalian neurofilament polypeptides. J. Biol. Chem. 257: 10467-10470

Julien, J.-P., G. D. Smoluk, and W. E. Mushynski (1983) Characteristics of the protein kinase activity associated with rat neurofilament preparations. Biochim. Biophys. Acta 755: 25-31.

Kaspi, C., and W. E. Mushynski (1985) Characterization of interspe- cies size heterogeneity of the large subunit of mammalian neurofilaments. Ann. NY Acad. Sci. 455: 794-796.

Kaufmann, E., N. Geisler, and K. Weber (1984) SDS-PAGE strongly overestimates the molecular masses of the neurofilament proteins. FEBS Lett. 170: 81-84.

King, L. E., and M. Morrison (1976) The visualization of human erythrocyte membrane proteins and glycoproteins in SDS polyacrylamide gels employing a single staining procedure. Anal. Biochem. 71 : 223-230.

Ksiezak-Reding, H., and S.-H. Yen (1987) Two monoclonal antibodies recognize Alzheimer's neurofibrillary tangles, neurofilament and microtubule associated proteins. J. Neurochem. 48: 455-462.

Ksiezak-Reding, H., D. W. Dickson, P. Davies, and S.-H. Yen (1987) Recognition of tau epitopes by anti-neurofilament antibodies that bind to Alzheimer neurofibrillary tangles. Proc. Natl. Acad. Sci. USA 84: $3410-3414$.

Laemmli, U. K. (1970) Cleavage of structural proteins during assembly of the head of bacteriophage T4. Nature 227: 680-685.

Lasek, R. J., L. Phillips, M. J. Katz, and L. Autilio-Gambetti (1985) Function and evolution of neurofilament proteins. Ann. NY Acad. Sci. 455: 462-478.

Leterrier, J.-F., R. K. H. Liem, and M. L. Shelanski (1981) Preferential phosphorylation of the 150,000 molecular weight component of neurofilaments by a cyclic AMP-dependent, microtubule-associated protein kinase. J. Cell Biol. 90: 755-760.

Lowry, O. H., N. J. Rosebrough, A. L. Farr, and R. J. Randall (1951) Protein measurement with the Folin phenol reagent. J. Biol. Chem. 193: 265-275.

Minami, Y., and H. Sakai (1985) Dephosphorylation supresses the activity of neurofilament to promote tubulin polymerization. FEBS Lett. 185: 239-242.

Murphy, D. B. (1982) Assembly-disassembly purification and characterization of microtubule protein without glycerol. In Methods in Cell Biology, vol. 24A, L. Wilson, ed., pp. 31-49, Academic, New York

Murthy, A. S. N., and M. Flavin (1983) Microtubule assembly using the microtubule-associated protein MAP-2 prepared in defined states of phosphorylation with protein kinase and phosphatase. Eur. J. Biochem. 137: 37-46.

Murthy, A. S. N., G. T. Bramblett, and M. Flavin (1985) The sites at which brain microtubule-associated protein 2 is phosphorylated in vivo differ from those accessible to cAMP-dependent kinase in vitro. J. Biol. Chem. 260: 4364-4370.

Nakazato, Y., A. Sasaki, J. IIirato, and Y. Ishida (1984) Immunohistochemical localization of neurofilament protein in neuronal degenerations. Acta Neuropathol. (Berl.) 64: 30-36.

Nukina, N., K. S. Kosik, and D. J. Selkoe (1987) Recognition of Alzheimer paired helical filaments by monoclonal neurofilament antibodies is due to crossreaction with tau protein. Proc. Natl. Acad. Sci. USA 84: 3415-3419.

Runge, M. S., M. R. El-Maghrabi, T. H. Claus, S. J. Pilkis, and R. C. Williams (1981) A MAP-2-stimulated protein kinase activity associated with neurofilaments. Biochemistry 20: 175-180.

Selden, S. C., and T. D. Pollard (1983) Phosphorylation of microtubule-associated proteins regulates their interaction with actin filaments. J. Biol. Chem. 258: 7064-7071.

Shecket, G., and R. J. Lasek (1982) Neurofilament protein phosphorylation. Species generality and reaction characteristics. J. Biol. Chem. 257: 4788-4795.

Sternberger, L. A., and N. H. Sternberger (1983) Monoclonal antibodies distinguish phosphorylated and non-phosphorylated forms of neurofilaments in situ. Proc. Natl. Acad. Sci. USA 80: 6126-6130.

Sternberger, N. H., L. A. Sternberger, and J. Ulrich (1985) Aberrant neurofilament phosphorylation in Alzheimer disease. Proc. Natl. Acad. Sci. USA 82: 4274-4276.

Theurkauf, W. E., and R. B. Vallee (1982) Molecular characterization of the cAMP-dependent protein kinase bound to microtubule-associated protein-2. J. Biol. Chem. 257: 3284-3290.

Toru-Delbauffe, D., and M. Pierre (1983) A rat brain protein kinase phosphorylating specifically neurofilaments. FEBS Lett. 162: 230234.

Towbin, H., T. Staehelin, and J. Gordon (1979) Electrophoretic transfer of proteins from polyacrylamide gels to nitrocellulose sheets: Procedure and some applications. Proc. Natl. Acad. Sci. USA 76: $4350-4354$. 
Troncoso, J. C., L. A. Sternberger, N. H. Sternberger, P. N. Hoffman, and D. L. Price (1985) Immunocytochemical studies of neurofilament antigens in the neurofibrillary pathology induced by aluminum [abstract]. J. Neuropathol. Exp. Neurol. 44: 332.

Vallano, M. L., T. M. Buckholz, and R. J. DeLorenzo (1985) Phosphorylation of neurofilament proteins by endogenous calcium/calmodulin-dependent protein kinase. Biochem. Biophys. Res. Commun. 130: 957-963.

Willard, M., and C. Simon (1981) Antibody decoration of neurofilaments. J. Cell Biol. 89: 198-205.
Wong, J., S. B. Hutchison, and R. K. H. Liem (1984) An isoelectric variant of the 150,000 -dalton neurofilament polypeptide. Evidence that phosphorylation state affects its association with the filament. J. Biol. Chem. 259: 10867-10874.

Yen, S.-H., H. Reding, P. Davies, and G. Ciment (1985) The compositions of neurofibrillary tangles of the senile dementia of Alzheimer type: An immunological study. Ann. NY Acad. Sci. 455: 819-825. 